J. Lake Sci. (湖泊科学), 2020, 32(6): 1793-1805

DOI 10. $18307 / 2020.0619$

(c) 2020 by Journal of Lake Sciences

\title{
渭河干流和秦岭北麓典型支流底栖动物群落结构及水质生物评价”
}

\author{
杨海强, 潘保柱 ${ }^{* *}$, 朱朋辉, 蒋万祥, 蒋小明, 候易明 \\ (西安理工大学西北旱区生态水利国家重点实验室,西安 710048)
}

\begin{abstract}
摘 要: 为摸清渭河干流及源于秦岭北麓典型支流的大型底栖动物群落特征, 本研究于 2017 年 10 月和 2018 年 5 月对渭 河干流及秦岭北麓 5 条典型支流共 40 个样点的大型底栖动物进行调查, 并利用 Margalef 丰富度指数和生物指数 $B I$ 生物 指数对河流水质进行评价. 共鉴定大型底栖动物 210 种, 属于 5 门 8 纲 75 科 187 属. 水生昆虫为优势类群, 其物种数占总 物种数的 $89.0 \%$, 且四节蜉属一种 (Baetis sp.) 作为绝对优势的物种出现在所有调查河流中. 源于秦岭北麓的支流石头河 底栖动物总密度最高 $\left(616.3\right.$ ind. $\left./ \mathrm{m}^{2}\right)$, 总生物量最大 $\left(5.265 \mathrm{~g} / \mathrm{m}^{2}\right)$; 而渭河干流底栖动物总密度最低 $\left(125.6\right.$ ind. $\left./ \mathrm{m}^{2}\right)$, 总 生物量最小 $\left(0.289 \mathrm{~g} / \mathrm{m}^{2}\right)$. 水质较好的秦岭北麓典型支流底栖动物的 Shannon-Wiener 多样性指数、Margalef 丰富度指数显 著高于渭河干流, 而 Pielou 均匀度指数在干支流间的差异性不大. 通过 Pearson 相关分析和多元逐步回归分析得出, 淤泥 型底质、电导率、 $\mathrm{pH}$ 和硝酸盐氮是影响调查河流底栖动物群落特征的主导因子. 丰富度指数法和生物指数法水质评价结 果分别显示, 渭河干流有 $73.3 \%$ 和 $80.0 \%$ 的采样点呈中度一重度污染状态, 秦岭北麓典型支流有 $80.0 \%$ 和 $68.0 \%$ 的采样点 呈无污染一轻度污染状态. 本研究可为渭河流域生态管理与保护提供基础的数据支撑.
\end{abstract}

关键词: 大型底栖动物;群落结构;环境因子;水质评价;渭河流域;秦岭

\section{Structure of macroinvertebrate communities and bioassessment of water quality in the Weihe River mainstream and its typical tributaries from the northern Qinling Mountains*}

\author{
YANG Haiqiang, PAN Baozhu*** ZHU Penghui, JIANG Wanxiang, JIANG Xiaoming \& HOU Yiming \\ ( State Key Laboratory of Ecological Water Conservancy in the Northwest Arid Area, Xi'an University of Technology, Xi'an \\ 710048, P.R.China)
}

\begin{abstract}
For exploring the macroinvertebrate community characteristics of the Weihe River mainstream and its typical tributaries originating from the northern Qinling Mountains, investigation of water environment and macroinvertebrates was conducted in 40 sampling sites in October 2017 and May 2018. Furthermore, Margalef richness and biological index (BI) biological indices were used to assess the water quality of studied rivers. Altogether 210 macroinvertebrates species were identified, belonging to 187 genera, 75 families, 8 classes and 5 phyla. Aquatic insects were the dominant group, accounting for $89.0 \%$ of the total species number, and the Baetis sp. was the dominant species in all studied rivers. The tributary Shitou River, had the highest values of total density $\left(616.3\right.$ ind.$\left./ \mathrm{m}^{2}\right)$, and the highest total biomass $\left(5.265 \mathrm{~g} / \mathrm{m}^{2}\right)$. Whereas the total density $\left(125.6 \mathrm{ind} . / \mathrm{m}^{2}\right)$ and total biomass $\left(0.289 \mathrm{~g} / \mathrm{m}^{2}\right)$ of macroinvertebrates were both lowest in the Weihe River mainstream. The Shannon-Wiener diversity index $\left(H^{\prime}\right)$ and Margalef richness index $(R)$ of five typical tributaries were characterized by good water quality and significantly higher than those of the Weihe River mainstream, whereas the Pielou evenness index $(J)$ showed insignificant difference between mainstream and tributaries. Pearson correlation analysis and the multiple linear regression analysis showed that "Silt plus clay" type substrate, conductivity, $\mathrm{pH}$ and nitrate nitrogen were the primary environment factors effecting the macroinvertebrate community characteristics in studied rivers. According to the water quality evaluation results of the richness index and the $B I$ method, $73.3 \%$ and $80.0 \%$ of the mainstream sites were identified as moderately to heavily polluted, but $80.0 \%$ and $68.0 \%$ of tributary sites were identified as non-polluted to slightly polluted. This study can provide basic data supports for ecological management and protection in the Weihe River Basin.
\end{abstract}

* 2019-09-15 收稿; 2020-01-11 收修改稿.

国家自然科学基金项目 (51939009) 和陕西省自然科学基础研究计划项目 (2019JM-153) 联合资助.

** 通信作者; E-mail: zhuzipan@xaut.edu.cn. 
Keywords: Macroinvertebrate; community structure; environmental factors; water quality evaluation; Weihe River Basin; Qinling Mountain

渭河是黄河的第一大支流,担负着供水、灌溉、生态、旅游等功能,在区域经济发展中具有重要的地位. 秦岭为典型生态交错带, 发源于其北麓的溪流为渭河南岸的支流, 孕育了许多珍稀保护水生生物, 是我国重 要的生物多样性保护基地, 也是居民生活生产的水源地. 然而近些年来, 由于气候干旱和人类活动的加剧, 渭河面临着水量减少、水质退化、生物多样性降低等问题 ${ }^{[-2]}$. 秦岭北麓地区由于水利工程的建设、区域经济 的发展及现代化进程的加剧, 使得自然水文情势及水环境特征发生改变 ${ }^{[3]}$. 而水生生物受水文情势、水体理 化特征等多种环境因素的综合影响, 其群落结构对环境变化的响应具有高度敏感性, 能快速反映不同时空 尺度上水体的变化特征,是表征河流生态环境状况的重要指标 ${ }^{[4-6]}$.

在水生生物中,生活史的全部或大部分时间生活于水体底部且个体大于 $500 \mu \mathrm{m}$ 的水生动物群被称之 为大型底栖无脊椎动物或大型底栖动物 ${ }^{[7]}$. 大型底栖动物移动能力较弱, 生活史较长, 各个类群的生境倾向 性差异很大, 群落结构能够很好地指示水体环境质量, 被广泛用于环境响应分析 ${ }^{[8-10]}$ 及水生态系统健康评价 的研究中 ${ }^{[1-1-1]}$. 在温暖湿润的区域,受人类干扰小的自然河流大型底栖动物群落明显特征是生物多样性相 对较高、生物量相对较大 ${ }^{[15-16]}$, 而少雨干旱、年内一定时期温度较低的区域 (如渭河流域), 底栖动物一般资 源量较低. 渭河干流因其特有的地理位置、气候条件以及人类活动的影响致使其突显出高含沙、污染较重等 特点, 以致水生态环境比较脆弱; 源于秦岭的溪流对维系渭河流域生物多样性起着举足轻重的作用, 然而近 年来由于水电站建设、挖沙、部分生活污水流人等原因导致某些河段生态状况堪忧. 鉴于大型底栖动物对水 生态健康水平的良好指示作用以及渭河干流和秦岭北麓溪流的重要性, 以底栖动物作为指示生物全面系统 地评估此区域的水生态健康水平是非常有必要的. 然而, 仅殷旭旺等在渭河流域开展过底栖动物群落结构 及水体环境分析的相关研究 ${ }^{[17-18]}$, 其绝大多数样点布设于渭河北岸支流, 渭河干流和秦岭北麓支流仅布设 15 个样点, 且每个样点只采集了 2 个平行样品, 由此可见, 以往研究比较薄弱, 不足以全面地了解渭河干流 及源于秦岭北麓支流的生态环境现状.

鉴于此,本研究选取渭河干流全河段及发源于秦岭北麓的 5 条支流作为研究对象, 于 2017 年 10 月及 2018 年 5 月开展了系统的、大尺度的水环境和水生生物调查研究. 本文的研究目标为: 1) 摸清渭河干流及秦 岭北麓典型支流大型底栖动物的群落特征;2) 分析渭河干流及秦岭北麓典型支流大型底栖动物群落差异及 其成因;3) 以大型底栖动物作为指示生物对渭河干流及秦岭北麓典型支流进行水质生物学评价.

\section{1 研究区域与方法}

\section{1 研究区域概况及样点设置}

渭河是黄河最大的支流, 发源于甘肃省渭源县鸟鼠山, 主要流经甘肃省的天水市、陕西省的宝鸡、咸阳、 西安、渭南等地,至渭南市潼关县汇人黄河,全长 $818 \mathrm{~km}$, 流域面积 13.43 万 $\mathrm{km}^{2}$. 该流域位于东西走向的秦 岭北部, 其上段流经黄土高原沟壑区, 挟带大量的泥沙, 河道山峡相间纵横, 下段主要为秦陇山区, 流域地貌 复杂. 渭河年际径流量变化表现为北部大, 南部小; 季节变化明显, 干流以秋季流量最大, 约占年径流的 $38 \% \sim 40 \%{ }^{[19]}$. 近些年来, 渭河流域非点源污染物排放量增大, 加上关中地区水资源缺乏, 大多数城市供水, 工农业用水主要来源于渭河干流和支流, 导致渭河生态需水量减少且多年来生态环境建设不足, 严重降低 了渭河的生态自净能力 ${ }^{[20-21]}$.

本研究于 2017 年 10 月及 2018 年 5 月共两次以渭河干流和秦岭北麓的石头河、黑河、灞河、石堤河、罗 敷河 5 条典型支流作为研究对象, 开展了系统的、大尺度的生态调查. 在具有不同生境、流速、水深的地方布 设具有代表性的采样点, 干流共设 15 个采样点, 每条支流各设 5 个采样点, 每个采样点均采集 5 个平行样 品,两次调查共采集到 400 个样品. 研究区域及调查河流见图 1.

\section{2 样品采集与处理}

在各个水生态调查位点处选取河流代表河段 $100 \mathrm{~m}$ 范围内, 用篎网孔径 $420 \mu \mathrm{m}$ 、网口宽度 $30 \mathrm{~cm}$ 的手 持 $\mathrm{D}$ 型网采集大型底栖动物, 每个样方面积为 $0.3 \mathrm{~m}^{2}$. 采集到的底栖动物于室内进行人工挑拣, 分拣出的底 


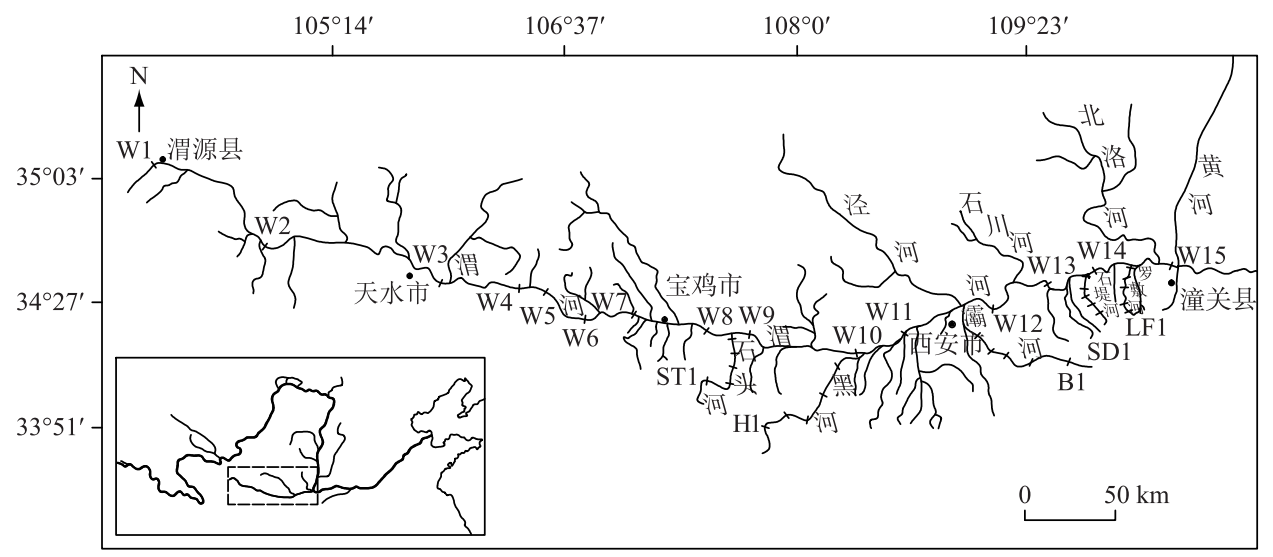

图 1 渭河干流及秦岭北麓支流采样点分布

（W-渭河干流,ST-石头河,H-黑河, B-灞河,SD-石堤河,LF-罗敷河）

Fig.1 Distribution of sampling sites in the Weihe River mainstream and its tributaries from the northern Qinling Mountains

栖动物标本放人 $50 \mathrm{~mL}$ 的样品瓶中, 并加人浓度为 $75 \%$ 的酒精固定. 将样品带回实验室后依照国内外相关 参考资料在体视镜和显微镜下进行种类鉴定 ${ }^{[22-24]}$ 、计数和称湿重. 鉴定完成的底栖动物, 继续放回样品瓶 中,方便后期鉴定和复核.

\section{3 环境因子测定}

在对渭河流域各样点的理化因子进行测定时, 采用哈希 HQ40D 便携式多参数分析仪对电导率、溶解 氧、水温、 $\mathrm{pH}$ 等水质参数现场测定; 浊度采用哈希 $2100 \mathrm{Q}$ 便携式浊度仪进行现场测定; 水深采用测深尺现场 涉水测量; 流速采用 Global Water FP211 直读式仪器进行现场测量, 测量时将流速仪放人距离水面约 1/3 水 深处的水体中, 螺旋桨正对水流顺流的方向进行测量. 在采样点的表、底层取水样混合, 带回实验室分析, 总 氮 $(\mathrm{TN})$ 、总磷 $(\mathrm{TP})$ 、氨氮 $\left(\mathrm{NH}_{3}-\mathrm{N}\right)$ 、硝酸盐氮 $\left(\mathrm{NO}_{3}^{-}-\mathrm{N}\right)$ 、亚硝酸盐氮 $\left(\mathrm{NO}_{2}^{-}-\mathrm{N}\right)$ 等营养盐根据《水和废水监测 分析方法》 (第三版) 测定 ${ }^{[25]}$. 在各采样点取水样 $1 \mathrm{~L}$, 在低温 $0 \sim 4^{\circ} \mathrm{C}$ 避光处保存, 加 $1 \mathrm{~mL}$ 浓度为 $1 \%$ 碳酸镁 悬浊液以防止由于酸化引起的色素溶解, 水体叶绿素 $a$ 浓度采用热乙醇一分光光度计法测定 ${ }^{[26]}$. 底质类型 划分依据为: 淤泥 (Silt plus clay, $<0.05 \mathrm{~mm}$ )、沙 (Sand, $0.05 \sim 2 \mathrm{~mm}$ )、砾石 (Gravel, 2 16 mm)、小卵石 (Pebble, 16 64 mm)、卵石 (Cobble, 64 256 mm) 和大石 (Boulder, >256 mm) ${ }^{[27]}$.

\section{4 水质生物评价}

利用 Margalef 丰富度指数 $(R)$ 和生物指数 $B I$ 进行水质生物评价 ${ }^{[28]}$.

$$
B I=\sum_{i=1}^{n} \frac{n_{i} t_{i}}{N}
$$

式中, $n_{i}$ 是样本中第 $i$ 种的个体数; $t_{i}$ 是样本中第 $i$ 个分类单元的耐污值; $N$ 是样本总个体数.

参考 Karr 等 ${ }^{[29-32]}$ 使用的水质生物评价指数值与分值的转化方法, 计算 $B I$ 指数水质评价分级标准. 具体 选择方法为: 应用所有样点的 $B I$ 值, 通过频数分析, 以 $5 \%$ 分位数对应的值作为标准, 小于该值表示水质最 清洁 ( I ), 对大于该值至最大值的数值四等分, 分值从小到大依次分别代表清洁 ( II )、轻污染 ( III)、中污染 (IV) 和重污染 $(\mathrm{V})$. 计算使用的大型底栖动物耐污值参考文献[33-36].

\section{5 数据分析}

采用 Shannon-Wiener 多样性指数 $\left(H^{\prime}\right)^{[37]}$ 、Margalef 丰富度指数 $(R)^{[38]}$ 和 Pielou 均匀度指数 $(J)^{[39]}$ 分析 渭河流域底栖动物的多样性; 用 Berger-Parker 优势度指数 $(Y)$ 判定优势 ${ }^{\left[{ }^{[}\right.}{ }^{[40]}$ :

$$
H^{\prime}=-\sum_{i=1}^{s} P_{i} \ln P_{i}
$$




$$
\begin{gathered}
R=(S-1) / \ln N \\
J=H^{\prime} / \log _{2} S \\
Y=P_{i} \cdot f_{i}
\end{gathered}
$$

式中, $S$ 为样本中的总物种数; $N$ 为总个体数; $P_{i}=n_{i} / N, n_{i}$ 为第 $i$ 种个体数, $P_{i}$ 为第 $i$ 种在总数量中的比例; $f_{i}$ 为该种出现的样点数占总样点的百分比. $Y \geqslant 0.02$ 时, 该种即为优势种.

对渭河干流和秦岭北麓典型支流的两次大型底栖动物采样数据做平均处理, 用两个季度的平均值反映 底栖动物一整年的情况. 对服从正态分布的数据, 使用单因素方差分析 (One-way ANOVA) 比较环境参数、生 物多样性指数、底栖动物不同种类类群的密度和生物量在不同河流间 (渭河干流和 5 条支流) 的差异性. 若 组间差异显著, 则用 LSD 法 (方差齐性) 和 Games-Howell 法(方差不齐) 进行多重比较. 对不服从正态分布的 数据则利用 Kruskal-Wallis Test ( H) 进行非参数检验. 最后, 采用 Pearson 相关性分析和多元线性逐步回归分 析 (Multiple linear regression analysis) 探究底栖动物的群落特征与环境因子的关系. 以上分析均在 IBMSPSS 25.0 软件中进行. 绘图使用的软件为 OriginPro 9.1 .

\section{2 结果}

\section{1 水环境特征}

本次调查共监测环境因子 19 项,调查结果如表 1. 对不同河流间环境因子的差异性分析表明,水温、浊 度、电导率、 $\mathrm{pH}$ 、总磷、总氮、氨氮、硝酸盐氮、淤泥、沙和卵石底质等环境参数在渭河干流及秦岭北麓典型支 流间具有显著差异 $(P<0.01)$, 而其他环境参数在调查河流间的差异不显著 $(P>0.05)$.

\begin{tabular}{|c|c|c|c|c|c|c|c|}
\hline 水环境参数 & 渭河 & 石头河 & 黑河 & 灞河 & 石堤河 & 罗敷河 & $P$ \\
\hline 水温 $/{ }^{\circ} \mathrm{C}$ & $14.5 \pm 2.4^{\mathrm{b}}$ & $13.2 \pm 1.3^{b}$ & $13.1 \pm 4.1^{\mathrm{b}}$ & $18.5 \pm 3.8^{\mathrm{a}}$ & $16.9 \pm 1.3^{\mathrm{ab}}$ & $14.9 \pm 0.9^{b}$ & 0.010 \\
\hline 水深 $/ \mathrm{cm}$ & $18.9 \pm 5.1^{\mathrm{a}}$ & $18.4 \pm 2.2^{\mathrm{a}}$ & $19.8 \pm 3.3^{\mathrm{a}}$ & $18.2 \pm 4.6^{\mathrm{a}}$ & $16.6 \pm 4.0^{\mathrm{a}}$ & $19.2 \pm 2.4^{\mathrm{a}}$ & 0.871 \\
\hline 流速 $/(\mathrm{m} / \mathrm{s})$ & $0.5 \pm 0.3^{\mathrm{a}}$ & $0.8 \pm 0.2^{\mathrm{a}}$ & $0.7 \pm 0.4^{\mathrm{a}}$ & $0.6 \pm 0.2^{\mathrm{a}}$ & $0.6 \pm 0.5^{\mathrm{a}}$ & $0.8 \pm 0.3^{\mathrm{a}}$ & 0.429 \\
\hline 浊度/NTU & $659.2 \pm 394.0^{\mathrm{a}}$ & $6.8 \pm 1.6^{\mathrm{b}}$ & $3.0 \pm 4.2^{\mathrm{b}}$ & $14.0 \pm 13.3^{\mathrm{b}}$ & $15.0 \pm 11.5^{\mathrm{b}}$ & $7.4 \pm 3.4^{\mathrm{b}}$ & 0 \\
\hline 电导率/ $(\mu \mathrm{S} / \mathrm{cm})$ & $667.8 \pm 117.1^{\mathrm{a}}$ & $205.8 \pm 101.7^{\mathrm{b}}$ & $154.4 \pm 79.5^{\mathrm{b}}$ & $293.4 \pm 73.6^{\mathrm{b}}$ & $499.4 \pm 253.3^{\mathrm{ab}}$ & $341.0 \pm 117.1^{\mathrm{b}}$ & $\mathbf{0}$ \\
\hline 溶解氧/(mg/L) & $9.0 \pm 1.1^{\mathrm{a}}$ & $9.3 \pm 0.5^{\mathrm{a}}$ & $9.7 \pm 0.5^{\mathrm{a}}$ & $9.5 \pm 0.3^{\mathrm{a}}$ & $9.4 \pm 0.6^{\mathrm{a}}$ & $8.7 \pm 0.5^{\mathrm{a}}$ & 0.350 \\
\hline $\mathrm{pH}$ & $8.3 \pm 0.3^{\mathrm{a}}$ & $8.3 \pm 0.1^{\mathrm{a}}$ & $8.5 \pm 0.3^{\mathrm{a}}$ & $8.5 \pm 0.2^{\mathrm{a}}$ & $8.0 \pm 0.1^{b}$ & $7.6 \pm 0.2^{b}$ & $\mathbf{0}$ \\
\hline 总磷 $/(m g / L)$ & $0.051 \pm 0.0141^{\mathrm{b}}$ & $0.037 \pm 0.005^{\mathrm{bc}}$ & $0.015 \pm 0.005^{\mathrm{c}}$ & $0.041 \pm 0.004^{\mathrm{bc}}$ & $0.091 \pm 0.077^{\mathrm{a}}$ & $0.016 \pm 0.003^{\mathrm{c}}$ & 0.001 \\
\hline 总氮 $/(\mathrm{mg} / \mathrm{L})$ & $6.508 \pm 0.622^{\mathrm{a}}$ & $3.351 \pm 1.026^{\mathrm{b}}$ & $2.425 \pm 1.208^{\mathrm{b}}$ & $4.586 \pm 1.065^{\mathrm{ab}}$ & $4.916 \pm 0.925^{\mathrm{ab}}$ & $3.520 \pm 0.293^{\mathrm{b}}$ & $\mathbf{0}$ \\
\hline 氨氮 $/(\mathrm{mg} / \mathrm{L})$ & $1.664 \pm 0.331^{\mathrm{a}}$ & $1.273 \pm 0.128^{\mathrm{b}}$ & $1.064 \pm 0.545^{\mathrm{a}}$ & $0.897 \pm 0.271^{\mathrm{b}}$ & $0.800 \pm 0.352^{\mathrm{b}}$ & $0.701 \pm 0.152^{\mathrm{c}}$ & $\mathbf{0}$ \\
\hline 硝酸盐氮/(mg/L) & $4.473 \pm 0.790^{\mathrm{a}}$ & $1.756 \pm 0.945^{\mathrm{c}}$ & $0.977 \pm 0.605^{\mathrm{d}}$ & $3.060 \pm 0.748^{\mathrm{b}}$ & $3.069 \pm 0.563^{\mathrm{b}}$ & $2.056 \pm 0.189^{\mathrm{c}}$ & $\mathbf{0}$ \\
\hline 亚硝酸盐氮/(mg/L) & $0.110 \pm 0.064^{\mathrm{a}}$ & $0.134 \pm 0.028^{\mathrm{a}}$ & $0.088 \pm 0.051^{\mathrm{a}}$ & $0.211 \pm 0.093^{\mathrm{a}}$ & $0.373 \pm 0.489^{\mathrm{a}}$ & $0.147 \pm 0.034^{\mathrm{a}}$ & 0.110 \\
\hline 叶绿素 $a /(\mathrm{mg} / \mathrm{L})$ & $0.026 \pm 0.026^{\mathrm{a}}$ & $0.008 \pm 0.005^{\mathrm{a}}$ & $0.007 \pm 0.010^{\mathrm{a}}$ & $0.012 \pm 0.006^{\mathrm{a}}$ & $0.016 \pm 0.024^{\mathrm{a}}$ & $0.003 \pm 0.002^{\mathrm{a}}$ & 0.145 \\
\hline 淤泥/\% & $31.4 \pm 26.2^{\mathrm{a}}$ & $0.8 \pm 1.8^{\mathrm{b}}$ & $0.4 \pm 0.9^{\mathrm{b}}$ & $1.0 \pm 2.2^{\mathrm{b}}$ & $25.2 \pm 32.7^{\mathrm{ab}}$ & $18.4 \pm 41.1^{\mathrm{ab}}$ & 0.007 \\
\hline 沙/\% & $31.2 \pm 20.3^{\mathrm{a}}$ & $11.4 \pm 20.6^{\mathrm{b}}$ & $6.4 \pm 6.2^{\mathrm{b}}$ & $7.2 \pm 5.4^{\mathrm{b}}$ & $27.0 \pm 30.0^{\mathrm{ab}}$ & $3.3 \pm 2.2^{\mathrm{b}}$ & 0.019 \\
\hline 砾石/\% & $4.6 \pm 6.2^{\mathrm{a}}$ & $4.2 \pm 6.9^{\mathrm{a}}$ & $1.6 \pm 3.0^{\mathrm{a}}$ & $0.4 \pm 0.5^{\mathrm{a}}$ & $0.8 \pm 1.1^{\mathrm{a}}$ & $1.5 \pm 2.2^{\mathrm{a}}$ & 0.488 \\
\hline 小卵石/\% & $14.2 \pm 15.7^{\mathrm{a}}$ & $16.6 \pm 9.6^{\mathrm{a}}$ & $18.9 \pm 17.9^{\mathrm{a}}$ & $19.2 \pm 8.5^{\mathrm{a}}$ & $6.4 \pm 6.3^{\mathrm{a}}$ & $18.8 \pm 8.4^{\mathrm{a}}$ & 0.396 \\
\hline 卵石/\% & $18.1 \pm 22.0^{\mathrm{b}}$ & $62.4 \pm 25.7^{\mathrm{a}}$ & $66.0 \pm 21.8^{\mathrm{a}}$ & $54.6 \pm 20.3^{\mathrm{a}}$ & $39.2 \pm 43.5^{\mathrm{a}}$ & $54.4 \pm 31.4^{\mathrm{a}}$ & 0.006 \\
\hline 大石/\% & $0.8 \pm 3.2^{\mathrm{a}}$ & $9.6 \pm 11.5^{\mathrm{a}}$ & $7.0 \pm 9.6^{\mathrm{a}}$ & $17.6 \pm 30.3^{\mathrm{a}}$ & $1.4 \pm 3.1^{\mathrm{a}}$ & $3.6 \pm 5.1^{\mathrm{a}}$ & 0.160 \\
\hline
\end{tabular}

表 1 渭河流域调查河流的环境参数 *

Tab.1 Water environment parameters in studied rivers of the Weihe River Basin

* 同一行上标不同小写字母表示存在显著差异 $(P<0.05)$.

\section{2 底栖动物物种组成}

调查期间于渭河干流及秦岭北麓典型支流 40 个样点采集并鉴定大型底栖动物 210 种, 隶属于 5 门 8 纲 75 科 187 属, 其中节肢动物 192 种 (昆虫纲 187 种, 蛛形纲 1 种, 甲壳纲 4 种), 环节动物 11 种 (寡毛纲 9 种, 蛭纲 2 种), 软体动物 5 种, 扁形动物 1 种, 线虫动物 1 种. 
在渭河干流与 5 条秦岭北麓典型支流的大型底栖动物中, 底栖动物的物种数表现为支流多于干流, 且 以水生昆虫为绝对优势的类群. 渭河干流底栖动物物种数为 68 种, 水生昆虫占 $84.1 \%$; 石头河的物种数为 107 种, 水生昆虫占 $89.7 \%$; 黑河的物种数为 109 种, 水生昆虫占 $91.7 \%$; 灞河的物种数为 80 种, 水生昆虫占 $88.8 \%$; 石堤河的物种数为 70 种, 水生昆虫占 $88.6 \%$; 罗敷河的物种数为 63 种, 水生昆虫占 $87.3 \%$.

由优势度指数分析表明 (表 2), 四节蜉属一种 (Baetis sp.) 在 6 条河流中均为绝对优势种,霍甫水丝蚓 (Limnodrilus hoffmeisteri) 作为优势种均出现在渭河干流、灞河及石堤河中, 韦特直突摇蚊 (Orthocladius wetternsis) 作为优势种均出现在渭河干流及灞河中,其余优势种在调查河流中仅出现 1 次.

表 2 渭河流域调查河流中底栖动物的优势种

Tab.2 The dominant species of macroinvertebrates in studied rivers of the Weihe River Basin

\begin{tabular}{|c|c|}
\hline 河流 & 优势种 $\left(\right.$ 密度 $/\left(\right.$ ind. $\left./ \mathrm{m}^{2}\right)$,生物量 $/\left(\mathrm{g} / \mathrm{m}^{2}\right)$,优势度 $)$ \\
\hline 渭河干流 & $\begin{array}{l}\text { 四节蜉属一种 }(46.1,0.040,0.241) \text { 、霍甫水丝蚓 }(35.8,0.033,0.199) \text { 、梯形多足摇蚊 }(6.3,0.002,0.032) \\
\text { 纹石蛾属一种 }(7.9,0.023,0.023) \text { 、韦特直突摇蚊 }(5.3,0.002,0.021)\end{array}$ \\
\hline 石头河 & $\begin{array}{l}\text { 四节蜉属一种 }(226.9,0.319,0.359) \text { 、高翔蜉属一种 }(58.9,0.513,0.068) \text { 、线虫纲一种 }(68.1,0.681,0.065) \\
\text { 角石蛾属一种 }(4.7,0.461,0.042) \text { 、真蜗虫属一种 }(31.2,0.115,0.022)\end{array}$ \\
\hline 黑河 & 四节蜉属一种 $(50.2,0.102,0.171) 、$ 钩虾属一种 $(34.7,0.410,0.051)$ 、带肋蜉属一种 $(12.3,0.078,0.028)$ \\
\hline 灞河 & $\begin{array}{l}\text { 四节蜉属一种 }(67.7,0.077,0.220) 、 \text { 、韦特直突摇蚊 }(37.2,0.010,0.081) \text { 、霍甫水丝蚓 }(40.0,0.014,0.078) \\
\text { 石栖直突摇蚊 }(21.2,0.006,0.033)\end{array}$ \\
\hline 石堤河 & $\begin{array}{l}\text { 四节蜉属一种 }(60.4,0.149,0.302) \text { 、霍甫水丝蚓 }(13.7,0.007,0.027) \text { 、拟踵突多足摇蚊 }(13.5,0.007,0.026) \\
\text { 蚋属一种 }(5.3,0.007,0.021)\end{array}$ \\
\hline 罗敷河 & 四节蜉属一种 $(163.1,0.442,0.435) 、$ 花翅蜉属一种 $(58.1,0.141,0.141)$ \\
\hline
\end{tabular}

\section{3 底栖动物的密度和生物量}

渭河干流和秦岭北麓典型支流中大型底栖动物各种类类群的密度、生物量及百分比如表 3 所示, 调查 发现, 底栖动物总密度和昆虫纲的密度表现为石头河最高、渭河干流最低; 在 6 条调查河流不同种类类群 中,对水环境质量具有良好指示作用的 EPT 类 ( $\mathrm{E}$ : 蜉蝣目, P: 襀翅目, $\mathrm{T}$ : 毛翅目) 均为绝对优势的类群, 密度 和生物量占比均以罗敷河最高, 分别达 $78.3 \%$ 和 $92.1 \%$. 对调查河流不同河流间各种类类群差异性分析显 示, 骞毛纲的生物量、腹足纲的密度和生物量在调查河流间无显著差异 $(P>0.05)$ 外, 其他种类类群的密度 和生物量在调查河流间均具有显著差异 $(P<0.05)$.

\section{4 生物多样性}

在渭河干流中, $H^{\prime} 、 R$ 和 $J$ 的均值分别为 $1.16 、 1.69$ 和 0.77 , 范围分别在 $0.27 \sim 2.07 、 0.47 \sim 3.16$ 和 $0.51 \sim$ 0.97 之间. 在发源于秦岭北麓典型支流中, $H^{\prime} 、 R$ 和 $J$ 均值分别为 $1.86 、 3.28$ 和 0.74 , 范围分别在 $0.93 \sim 2.85$ 、 1.42 6.73 和 0.53 0.90 之间. 在空间尺度上, 调查河流中 $H^{\prime}$ 和 $R$ 变化规律表现出高度的一致性 (图 2), 且 除 $J$ 的差异性在不同河流间不显著外 $(P>0.05), H^{\prime}$ 和 $R$ 的差异性均极显著 $(P<0.001)$. 在具体河流中, 石 头河、黑河的 $H^{\prime}$ 和 $R$ 指数值要明显高于其他河流, 且 5 条秦岭北麓典型支流的 $H^{\prime}$ 和 $R$ 指数值均高于渭河 干流.

\section{5 水质生物学评价}

2.5.1 基于 Margalef 丰富度指数的水质评价 由 Margalef 丰富度指数水质等级划分标准 (表 4) 进行的水质 评价结果显示 (图 3), 在渭河干流和秦岭北麓典型支流的 40 个样点上, 最清洁 ( I )、清洁 ( II)、轻污染 (III) 和中污染 (IV) 的样点数量分别为 9 个、12 个、 3 个和 16 个, 水质评价等级为重污染 $(\mathrm{V})$ 的样点数为 0 个. 从调查河流不同河流间来看, 渭河干流水质较差, 水质等级处于轻污染 ( III ) 及以上的样点仅占 $27.0 \%$; 秦岭北麓溪流中的石头河、黑河、灞河、石堤河水质较好,水质等级处于清洁（II）及以上的样点均占 $80 \%$.

2.5.2 基于底栖动物 $B I$ 指数的水质评价 根据水质生物评价指数值与分值的转化方法, 计算得出 $B I$ 指数最 小值为 2.45 , 最大值为 $8.22,5 \%$ 分位数为 2.47 , 再由水质评价分级标准划分水质等级, 得出 $B I$ 指数的水质评 价标准(表 4).

由 $B I$ 指数法进行的水质评价结果显示 (图 3), 在渭河干流和秦岭北麓典型支流的 40 个采样点中, 水质 
表 3 渭河流域调查河流底栖动物各类群的密度 $\left(i n d . / \mathrm{m}^{2}\right)$ 和生物量 $\left(\mathrm{g} / \mathrm{m}^{2}\right)$ 以及其占比*

Tab.3 Density and biomass of each taxonomic groups of macroinvertebrates and its ratios in studied rivers of the Weihe River Basin

\begin{tabular}{|c|c|c|c|c|c|c|c|}
\hline 底栖动物 & & 渭河干流 & 石头河 & 黑河 & 灞河 & 石堤河 & 罗敷河 \\
\hline \multirow[t]{2}{*}{ 寡毛纲 } & 密度 & $\begin{array}{l}36.6 \pm 6.7 \\
(29.1 \%)^{a}\end{array}$ & $\begin{array}{l}8.3 \pm 4.7 \\
(1.3 \%)^{b}\end{array}$ & $\begin{array}{l}13.9 \pm 6.9 \\
(5.5 \%)^{\mathrm{a}}\end{array}$ & $\begin{array}{l}40.5 \pm 15.2 \\
(13.5 \%)^{\mathrm{a}}\end{array}$ & $\begin{array}{l}22.9 \pm 15.3 \\
(14.4 \%)^{\mathrm{a}}\end{array}$ & $\begin{array}{l}34.3 \pm 13.8 \\
(11.1 \%)^{\mathrm{a}}\end{array}$ \\
\hline & 生物量 & $\begin{array}{c}0.033 \pm 0.022 \\
(11.4 \%)^{\mathrm{a}}\end{array}$ & $\begin{array}{c}0.004 \pm 0.002 \\
(0.1 \%)^{\mathrm{a}}\end{array}$ & $\begin{array}{c}0.006 \pm 0.003 \\
(0.3 \%)^{\mathrm{a}}\end{array}$ & $\begin{array}{c}0.015 \pm 0.006 \\
(1.5 \%)^{\mathrm{a}}\end{array}$ & $\begin{array}{c}0.009 \pm 0.006 \\
(2.4 \%)^{\mathrm{a}}\end{array}$ & $\begin{array}{c}0.010 \pm 0.008 \\
(0.9 \%)^{\mathrm{a}}\end{array}$ \\
\hline \multirow[t]{2}{*}{ 腹足纲 } & 密度 & $\begin{array}{l}0.3 \pm 0.1 \\
(0.2 \%)^{\mathrm{a}}\end{array}$ & $\begin{array}{c}0.3 \pm 0.2 \\
(0.0 \%)^{\mathrm{a}}\end{array}$ & $\begin{array}{c}0.1 \pm 0.1 \\
(0.0 \%)^{\mathrm{a}}\end{array}$ & $\begin{array}{l}0.1 \pm 0.1 \\
(0.0 \%)^{\mathrm{a}}\end{array}$ & $\begin{array}{c}0.3 \pm 0.2 \\
(0.2 \%)^{\mathrm{a}}\end{array}$ & $\begin{array}{l}0.8 \pm 0.5 \\
(0.3 \%)^{\mathrm{a}}\end{array}$ \\
\hline & 生物量 & $\begin{array}{c}0.011 \pm 0.005 \\
(3.8 \%)^{\mathrm{a}}\end{array}$ & $\begin{array}{c}0.025 \pm 0.016 \\
(0.5 \%)^{\mathrm{a}}\end{array}$ & $\begin{array}{c}0.001 \pm 0.001 \\
(0.0 \%)^{\mathrm{a}}\end{array}$ & $\begin{array}{c}0.399 \pm 0.399 \\
(39.4 \%)^{\mathrm{a}}\end{array}$ & $\begin{array}{c}0.028 \pm 0.193 \\
(7.4 \%)^{\mathrm{a}}\end{array}$ & $\begin{array}{c}0.043 \pm 0.029 \\
(3.8 \%)^{\mathrm{a}}\end{array}$ \\
\hline \multirow[t]{2}{*}{ EPT 类 } & 密度 & $\begin{array}{l}59.1 \pm 10.1 \\
(47.1 \%)^{b}\end{array}$ & $\begin{array}{c}402.7 \pm 108.9 \\
(65.4 \%)^{\mathrm{a}}\end{array}$ & $\begin{array}{c}144.7 \pm 23.0 \\
(56.7 \%)^{\mathrm{a}}\end{array}$ & $\begin{array}{c}114.8 \pm 19.2 \\
(38.3 \%)^{\mathrm{a}}\end{array}$ & $\begin{array}{l}70.9 \pm 14.6 \\
(44.5 \%)^{\mathrm{a}}\end{array}$ & $\begin{array}{c}240.9 \pm 44.7 \\
(78.3 \%)^{\mathrm{a}}\end{array}$ \\
\hline & 生物量 & $\begin{array}{c}0.148 \pm 0.058 \\
(51.3 \%)^{b}\end{array}$ & $\begin{array}{c}3.630 \pm 0.695 \\
(68.9 \%)^{\mathrm{a}}\end{array}$ & $\begin{array}{c}1.343 \pm 0.308 \\
(63.3 \%)^{\mathrm{ab}}\end{array}$ & $\begin{array}{c}0.463 \pm 0.147 \\
(45.7 \%)^{\mathrm{b}}\end{array}$ & $\begin{array}{c}0.187 \pm 0.061 \\
(49.8 \%)^{b}\end{array}$ & $\begin{array}{c}1.046 \pm 0.298 \\
(92.1 \%)^{b}\end{array}$ \\
\hline \multirow[t]{2}{*}{ 其他昆虫纲 } & 密度 & $\begin{array}{l}23.0 \pm 3.4 \\
(18.3 \%)^{\mathrm{b}}\end{array}$ & $\begin{array}{c}60.6 \pm 11.8 \\
(9.8 \%)^{\mathrm{a}}\end{array}$ & $\begin{array}{l}46.3 \pm 10.4 \\
(18.2 \%)^{\mathrm{a}}\end{array}$ & $\begin{array}{c}126.4 \pm 27.0 \\
(42.2 \%)^{\mathrm{a}}\end{array}$ & $\begin{array}{l}64.7 \pm 22.0 \\
(40.7 \%)^{\mathrm{a}}\end{array}$ & $\begin{array}{l}28.9 \pm 5.6 \\
(9.4 \%)^{\mathrm{a}}\end{array}$ \\
\hline & 生物量 & $\begin{array}{c}0.027 \pm 0.006 \\
(9.3 \%)^{b}\end{array}$ & $\begin{array}{c}0.383 \pm 0.140 \\
(7.3 \%)^{\mathrm{a}}\end{array}$ & $\begin{array}{c}0.328 \pm 0.133 \\
(15.4 \%)^{\mathrm{a}}\end{array}$ & $\begin{array}{c}0.079 \pm 0.016 \\
(7.8 \%)^{b}\end{array}$ & $\begin{array}{c}0.149 \pm 0.076 \\
(39.6 \%)^{b}\end{array}$ & $\begin{array}{c}0.017 \pm 0.003 \\
(1.5 \%)^{b}\end{array}$ \\
\hline \multirow[t]{2}{*}{ 其他 } & 密度 & $\begin{array}{c}6.6 \pm 3.2 \\
(5.3 \%)^{b}\end{array}$ & $\begin{array}{c}144.4 \pm 31.6 \\
(23.5 \%)^{\mathrm{a}}\end{array}$ & $\begin{array}{l}50.0 \pm 18.8 \\
(19.6 \%)^{\mathrm{ab}}\end{array}$ & $\begin{array}{l}17.9 \pm 7.6 \\
(6.0 \%)^{b}\end{array}$ & $\begin{array}{c}0.3 \pm 0.1 \\
(0.2 \%)^{b}\end{array}$ & $\begin{array}{c}2.9 \pm 1.3 \\
(0.9 \%)^{b}\end{array}$ \\
\hline & 生物量 & $\begin{array}{c}0.070 \pm 0.325 \\
(24.2 \%)^{b}\end{array}$ & $\begin{array}{c}1.223 \pm 0.362 \\
(23.2 \%)^{\mathrm{a}}\end{array}$ & $\begin{array}{c}0.446 \pm 0.172 \\
(21.0 \%)^{\mathrm{ab}}\end{array}$ & $\begin{array}{c}0.057 \pm 0.029 \\
(5.6 \%)^{b}\end{array}$ & $\begin{array}{c}0.003 \pm 0.002 \\
(0.8 \%)^{b}\end{array}$ & $\begin{array}{c}0.020 \pm 0.015 \\
(1.7 \%)^{\mathrm{b}}\end{array}$ \\
\hline \multirow[t]{2}{*}{ 总计 } & 密度 & $\begin{array}{c}125.6 \pm 17.2 \\
(100 \%)^{b}\end{array}$ & $\begin{array}{c}616.3 \pm 138.8 \\
(100 \%)^{\mathrm{ab}}\end{array}$ & $\begin{array}{c}255.0 \pm 38.0 \\
(100 \%)^{b}\end{array}$ & $\begin{array}{c}299.9 \pm 41.4 \\
(100 \%)^{\mathrm{a}}\end{array}$ & $\begin{array}{c}159.1 \pm 37.7 \\
(100 \%)^{b}\end{array}$ & $\begin{array}{c}307.8 \pm 54.5 \\
(100 \%)^{\mathrm{a}}\end{array}$ \\
\hline & 生物量 & $\begin{array}{c}0.289 \pm 0.071 \\
(100 \%)^{\mathrm{c}}\end{array}$ & $\begin{array}{c}5.265 \pm 0.100 \\
(100 \%)^{\mathrm{a}}\end{array}$ & $\begin{array}{c}2.124 \pm 0.473 \\
(100 \%)^{b}\end{array}$ & $\begin{array}{c}1.013 \pm 0.464 \\
(100 \%)^{b}\end{array}$ & $\begin{array}{c}0.376 \pm 0.097 \\
(100 \%)^{\mathrm{b}}\end{array}$ & $\begin{array}{c}1.136 \pm 0.284 \\
(100 \%)^{b}\end{array}$ \\
\hline
\end{tabular}

* 同一行上标不同小写字母表示存在显著差异 $(P<0.05)$.

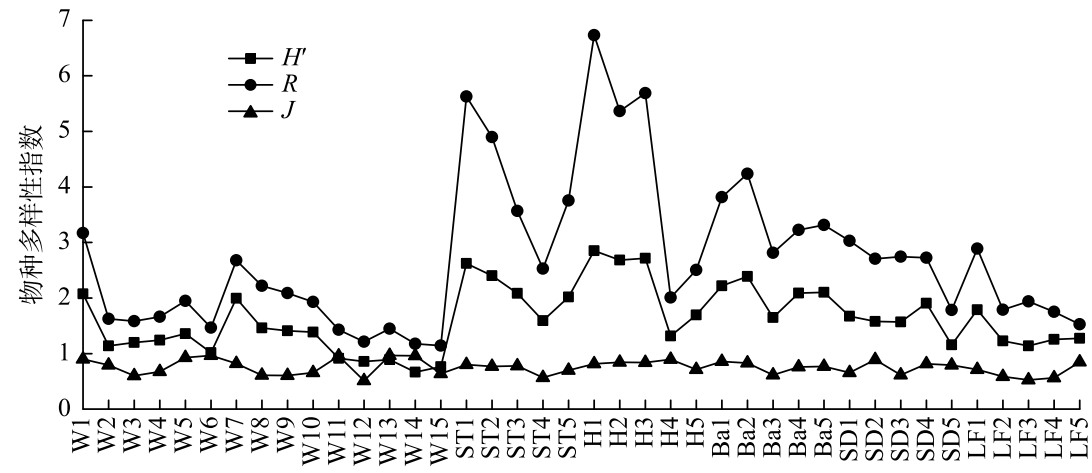

图 2 调查河流各采样点底栖动物多样性指数

Fig.2 Macroinvertebrate diversity indices of each site in studied rivers

评价为最清洁 ( I )、清洁 ( II )、轻污染 (III)、中污染 ( IV) 和重污染 ( V ) 的采样点数量分别为 2 个、16 个、13 个、6 个和 3 个. 从不同调查河流间来看, 渭河干流比秦岭北麓典型支流水质明显要差, 大多数采样点水质为 轻污染 $(I V)$ 到重污染 $(V)$, 污染较为严重; 秦岭北麓典型支流的水质明显要好, 在 5 条支流的 25 个采样点 
中, 有 $64.0 \%$ 的采样点水质等级处于清洁 ( II ) 及以上.

表 4 生物评价指数与水质等级划分标准

Tab.4 Biological evaluation index and graded standards of water quality

\begin{tabular}{cccccc}
\hline 生物评价指数 & 最清洁 $($ I $)$ & 清洁 $($ II $)$ & 轻污染 $($ III $)$ & 中污染 $($ IV $)$ & 重污染 $(\mathrm{V})$ \\
\hline Margalef 丰富度指数 & $>3.50$ & $2.50 \sim 3.50$ & $2.00 \sim 2.50$ & $1.00 \sim 2.00$ & $0 \sim 1.00$ \\
$B I$ 指数 & $<2.47$ & $2.47 \sim 3.91$ & $3.91 \sim 5.35$ & $5.35 \sim 6.78$ & $>6.78$ \\
\hline
\end{tabular}
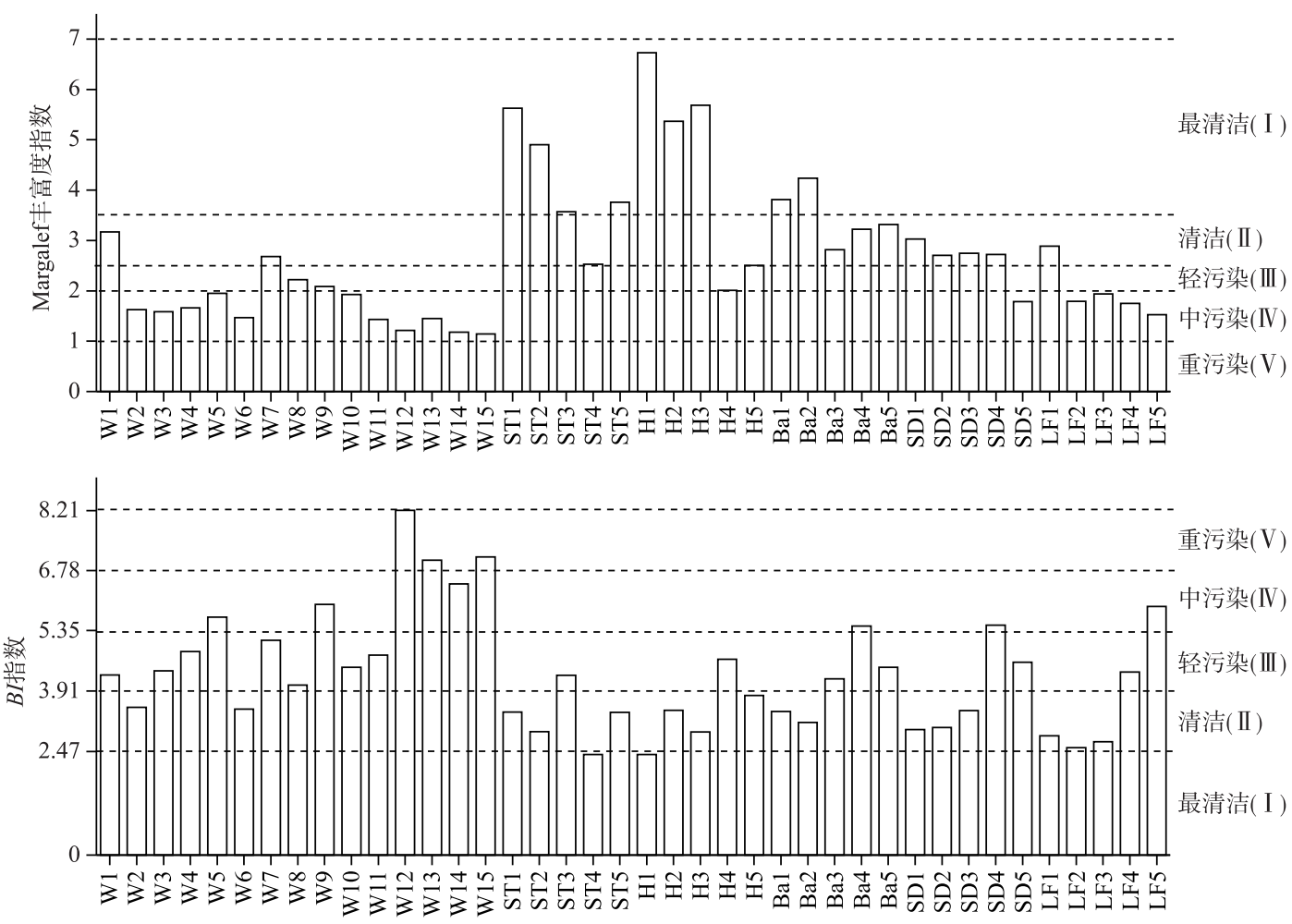

图 3 Margalef 丰富度指数和 $B I$ 指数水质评价结果

Fig.3 Results of water quality evaluation by Margalef index and BI method

\section{6 底栖动物与环境因子的相关性分析}

大型底栖动物的群落特征与环境因子的 Pearson 相关性分析 (表 5) 表明, 水温、浊度、流速、电导率、溶 解氧、 $\mathrm{pH}$ 、总氮、氨氮、硝酸盐氮、叶绿素 $a$ 等水环境因子以及淤泥、沙、卵石和大石等底质因子对底栖动物的 群落特征具有显著影响 $(P<0.05)$, 其他环境因子对底栖动物群落特征影响不显著 $(P>0.05)$.

通过多元逐步回归分析篮选出对渭河流域底栖动物密度、生物量、多样性指数和 $B I$ 指数变化相对重要 的水环境参数, 建立最优多元线性回归方程. 由表 6 可知, 底栖动物密度的回归方程有淤泥 1 个因子人选; 底栖动物生物量的回归方程有电导率 1 个因子人选; 底栖动物的 $H^{\prime}$ 有硝酸盐氮、 $\mathrm{pH}$ 、浊度和流速共 4 个因子 人选; 底栖动物的 $R$ 有硝酸盐氮、 $\mathrm{pH}$ 、氨氮、大石共 4 个因子人选; 底栖动物的 $J$ 有流速 1 个因子人选; $B I$ 指 数有叶绿素 $a$ 、淤泥和氨氮共 3 个因子人选. 方程的第一个自变量是因变量的绝对影响因子, 表明淤泥、电导 率、硝酸盐氮、流速、叶绿素 $a$ 这 5 种环境因子对底栖动物群落特征变化起决定性作用. 经 $F$ 检验, 方差分析 $F$ 值的显著水平 $P<0.05$, 表明回归显著. 
表 5 渭河流域调查河流底栖动物群落特征与环境因子的相关系数 $(r)$ 和概率水平 $(P)$

Tab.5 Correlation coefficient $(r)$ and probability $(P)$ studied level between macroinvertebrate community characteristics and environment factors in studied rivers of the Weihe River Basin

\begin{tabular}{|c|c|c|c|c|c|c|c|c|c|c|c|c|}
\hline \multirow{2}{*}{ 环境因子 } & \multicolumn{2}{|c|}{ 密度 } & \multicolumn{2}{|c|}{ 生物量 } & \multicolumn{2}{|c|}{$H^{\prime}$} & \multicolumn{2}{|l|}{$R$} & \multicolumn{2}{|l|}{$J$} & \multicolumn{2}{|l|}{$B I$} \\
\hline & $r$ & $P$ & $r$ & $P$ & $r$ & $P$ & $r$ & $P$ & $r$ & $P$ & $r$ & $P$ \\
\hline 水深 & -0.110 & 0.499 & -0.049 & 0.762 & -0.024 & 0.885 & -0.033 & 0.840 & 0.223 & 0.166 & -0.114 & 0.483 \\
\hline 水温 & -0.035 & 0.932 & -0.026 & 0.161 & -0.295 & 0.064 & $-0.378^{*}$ & 0.016 & -0.100 & 0.538 & 0.301 & 0.059 \\
\hline 浊度 & $-0.343^{*}$ & 0.030 & -0.309 & 0.052 & -0.542 & 0 & -0.503 ** & 0.001 & 0.146 & 0.370 & $-0.424^{* *}$ & 0.006 \\
\hline 流速 & 0.245 & 0.127 & 0.300 & 0.060 & 0.302 & 0.058 & $0^{0.358}{ }^{*}$ & 0.023 & $-0.321 *$ & 0.043 & $0.431^{* *}$ & 0.006 \\
\hline 电导率 & $-0.313^{*}$ & 0.049 & $-0.413^{* *}$ & 0.008 & -0.681 ** & 0 & -0.718 ** & 0 & 0.038 & 0.817 & 0.591 ** & 0 \\
\hline DO & 0.058 & 0.723 & 0.071 & 0.663 & $\mathbf{0 . 3 3 0}$ * & 0.038 & 0.306 & 0.054 & -0.254 & 0.114 & -0.044 & 0.789 \\
\hline $\mathrm{pH}$ & -0.023 & 0.886 & 0.076 & 0.640 & $0.484^{\text {** }}$ & * 0.002 & 0.450 *** & 0.004 & 0.285 & 0.075 & -0.127 & 0.435 \\
\hline $\mathrm{TP}$ & -0.118 & 0.467 & -0.183 & 0.258 & -0.206 & 0.203 & -0.250 & 0.120 & 0.103 & 0.526 & 0.278 & 0.082 \\
\hline $\mathrm{TN}$ & -0.169 & 0.297 & $-0.349 *$ & 0.027 & $-0.643^{* *}$ & 0 & $-0.709^{* * *}$ & 0 & -0.050 & 0.761 & $0.609^{* *}$ & 0 \\
\hline 氨氮 & -0.095 & 0.558 & -0.110 & 0.498 & -0.309 & 0.052 & $-0.388 *$ & 0.013 & 0.110 & 0.498 & $0.360 *$ & 0.022 \\
\hline 硝酸盐氮 & -0.168 & 0.300 & $-0.325 *$ & 0.041 & $-0.709^{* *}$ & 0 & $-0.738^{\text {** }}$ & 0 & -0.054 & 0.741 & $0.675^{* *}$ & 0 \\
\hline 亚硝酸盐氮 & -0.090 & 0.582 & -0.092 & 0.571 & -0.142 & 0.383 & -0.158 & 0.331 & 0.055 & 0.736 & 0.122 & 0.455 \\
\hline 叶绿素 $a$ & -0.280 & 0.080 & -0.270 & 0.092 & -0.532 & * 0 & -0.438 *** & 0.005 & 0.088 & 0.589 & $0.721^{* *}$ & 0 \\
\hline 淤泥 & $-0.561^{* *}$ & 0 & -0.372 * & 0.018 & -0.507 ** & * 0.001 & $-0.463^{\text {*** }}$ & 0.003 & 0.167 & 0.303 & $0.617^{* *}$ & 0 \\
\hline 沙 & $-0.365^{*}$ & 0.020 & $-0.360 *$ & 0.023 & -0.522 & * 0.001 & $-0.485^{\text {*** }}$ & 0.002 & 0.303 & 0.057 & 0.460 ** & 0.003 \\
\hline 砾石 & 0.100 & 0.541 & -0.034 & 0.836 & -0.116 & 0.475 & -0.182 & 0.262 & -0.199 & 0.219 & 0.031 & 0.848 \\
\hline 小卵石 & 0.281 & 0.079 & 0.075 & 0.644 & 0.061 & 0.709 & -0.081 & 0.621 & -0.284 & 0.075 & -0.266 & 0.097 \\
\hline 卵石 & 0.305 & 0.056 & 0.338 * & 0.033 & 0.635 ** & $* 0$ & 0.642 & 0 & -0.160 & 0.325 & $-0.653^{* *}$ & 0 \\
\hline 大石 & 0.300 & 0.060 & 0.354 * & 0.025 & $0.317^{*}$ & 0.046 & 0.315 * & 0.048 & -0.091 & 0.575 & -0.163 & 0.315 \\
\hline
\end{tabular}

* 表示显著相关, $P<0.05$ (双尾检验)；**表示极显著相关, $P<0.01$ (双尾检验).

\section{表 6 底栖动物群落特征与环境因子的逐步回归分析}

Tab.6 Multiple linear regression analysis between macroinvertebrate community characteristics and environment factors in studied rivers

\begin{tabular}{ccccc}
\hline 群落特征 & 回归方程 $($ 系数标准化 $)$ & 调整后 $R^{2}$ & $F$ & $P$ \\
\hline 密度 & 密度 $=-0.372 \times$ 淤泥 $\%$ & 0.116 & 6.112 & 0.018 \\
生物量 & 生物量 $=-0.413 \times$ 电导率 & 0.149 & 7.810 & 0.008 \\
$H^{\prime}$ & $H^{\prime}=-0.381 \times$ 硝酸盐氮 $+0.597 \times \mathrm{pH}-0.393 \times$ 浊度 $+0.199 \times$ 流速 & 0.813 & 43.357 & $<0.001$ \\
$R$ & $R=-0.563 \times$ 硝酸盐氮 $+0.545 \times \mathrm{pH}-0.299 \times$ 氨氮 $+0.180 \times$ 大石 $\%$ & 0.814 & 43.665 & $<0.001$ \\
$J$ & $B=-0.321 \times$ 流速 & 0.079 & 4.367 & 0.043 \\
$B I$ & $B I=0.548 \times$ 叶绿素 $a+0.349 \times$ 淤泥 $\%+0.237 \times$ 氨氮 & 0.670 & 27.373 & $<0.001$ \\
\hline
\end{tabular}

\section{3 讨论}

\section{1 渭河干流及秦岭北麓典型支流大型底栖动物群落结构特征}

渭河流域共鉴定大型底栖动物 210 种, 水生昆虫占 $89.0 \%$,这与殷旭旺等 ${ }^{[18]}$ 于 2013 年在渭河全流域共 45 个样点的调查结果相似 (水生昆虫占 $78.4 \%$ ), 但本研究所鉴定的物种数要高于其调查的 116 种, 这可能 归因于秦岭水系中底栖动物的多样性高. 研究发现, 调查河流中不同河流间的优势种具有较大的差异性, 渭 河干流、石头河均有 5 种优势种, 黑河有 3 种优势种, 灞河、石堤河有 4 种优势种, 罗敷河优势种较少, 仅 2 种, 四节蜉属一种 (Baetis sp.) 作为优势种均出现在 6 条河流中. 5 条源于秦岭北麓典型支流的物种数 (平均 86 种) 要高于渭河干流的 69 种, 丰富度指数和多样性指数也都高于渭河干流, 这说明了秦岭山区支流的大 
型底栖动物生物资源量较为丰富, 生态环境质量要好于渭河干流. 密度和生物量是衡量底栖动物现存量的 重要指标 ${ }^{[41]}$, 渭河干流底栖动物的密度和生物量为 $125.6 \mathrm{ind} . / \mathrm{m}^{2}$ 和 $0.289 \mathrm{~g} / \mathrm{m}^{2}$, 而支流底栖动物的密度和 生物量处于 159.1 616.3 ind. $/ \mathrm{m}^{2}$ 和 0.376 5.265 g/ $\mathrm{m}^{2}$ 之间, 并且 EPT 类水生昆虫是造成干支流密度和生物 量具有显著差异的主要类群. 渭河干流及秦岭北麓典型支流底栖动物群落组成具有很大区别, 这主要归因 于干支流的自然背景及人类活动造成的污染不同.

\section{2 渭河干流及秦岭北麓典型支流大型底栖动物与环境因子的关系}

大量研究表明, 底质是影响大型底栖动物群落分布的重要环境因子, 因为绝大多数底栖动物都需要依 附于底质度过其大部分的生活史 ${ }^{[42]}$. 相关性分析结果显示, 淤泥底质显著降低了渭河干支流底栖动物的现 存量和多样性水平 $(P<0.05)$, 而卵石和大石等大石块底质类型对底栖动物的生物量及多样性水平呈显著的 正相关关系 $(P<0.01)$. 在本研究中, 渭河干流样点的底质类型多以淤泥和沙为主, 这种细碎的底质以及简单 的小生境会直接降低 EPT 类底栖动物的现存量. 而支流样点则具有较多的卵石及大石, 微生境异质性高, 为 大型底栖动物提供了更多的生存空间以及捕食、避难和产卵场所 ${ }^{[43]}$, 这些都有助于底栖动物抵御外界环境 的干扰并维系其较高的多样性及丰富度水平. 河流中的大型底栖动物受水体污染胁迫的响应比较敏感,水 质的改变会影响其群落的时空分布 ${ }^{[44]}$. 一般而言, 水体透明度越高, 底栖动物的生物多样性越高. 浊度是通 过影响光照透射率从而影响附着藻类和浮游植物的生长, 最终影响以此为食的底栖动物 ${ }^{[45-46]}$. 本研究也发 现, 底栖动物的多样性指数与浊度呈极显著的负相关关系, 浊度水平较低的秦岭北麓支流底栖动物的多样 性和丰富度指数均要高于渭河干流. $\mathrm{pH}$ 过高或过低都会影响底栖动物的生存, 多数大型底栖无脊椎动物喜 生存于略偏碱性的水体中, 而酸性水体对其生存不利 ${ }^{[47-48]}$. 渭河干流及秦岭北麓 5 条典型支流 $\mathrm{pH}$ 的差异性 不大 $(\mathrm{pH} 7.6 \sim 8.5)$, 水体均呈弱碱性, 说明渭河流域水体的酸碱性在一定范围内是适合底栖动物生存的.

相关性分析结果表明, $\mathrm{pH}$ 与 $H^{\prime}$ 和 $R$ 指数具有极显著的正相关关系, 说明水体的酸碱性对维持底栖动物 群落结构的稳定性具有重要意义. 水体中溶解的各种阴阳离子的浓度决定了水体电导率的高低, 而较多的 研究也证明水生生物类群受电导率的影响显著, 特别是对底栖动物物种生存和群落结构的稳定性 ${ }^{[49-50]}$. 殷 旭旺等 ${ }^{[18]}$ 在渭河流域底栖动物的研究中发现电导率显著影响了底栖动物的空间分布, 本文的研究结果也证 实了这一结论. 除此之外, 本文研究结果发现电导率与 $B I$ 值呈极显著的正相关关系, 说明底栖动物对电导 率的变化反应较敏感, 使得水体中耐污耐受性物种增多. 这与赵茜等对浑太河流域底栖动物的研究结果一 致, 电导率的升高显著降低了大型底栖动物敏感物种的的出现频率 ${ }^{[51]}$.

本研究调查的 40 个样点水质监测的结果表明, 渭河干流及 5 条支流中水体 $\mathrm{N} 、 \mathrm{P}$ 等营养盐水平较高, 人 为干扰造成的营养盐污染较为严重, 且干流受污染程度要高于支流. 四节蜉往往在轻度污染的水体中占优 势, 而颤蚓和摇蚊幼虫容易在中度一重度污染水体中占优势 ${ }^{[28]}$. 在调查河流中四节蜉作为绝对优势的物种 出现, 霍甫水丝蚓和摇纹幼虫作为优势种均出现在了 $\mathrm{N} 、 \mathrm{P}$ 浓度最高的渭河干流、灞河和石堤河中. 襀翅目、 线虫等清洁种则只出现在水质较为清洁, 人类干扰较小的支流中, 在渭河干流中没有分布. 这表明人类干扰 已对渭河干支流底栖动物群落结构特征产生了较大的影响. 研究结果也显示, $\mathrm{N} 、 \mathrm{P}$ 等营养盐水平与底栖动 物的多样性指数呈负相关关系, 硝酸盐氮浓度是影响底栖动物多样性指数和丰富度指数的绝对影响因子, 说明调查河流水体营养盐污染导致了底栖动物生物多样性的降低.

$\mathrm{N} 、 \mathrm{P}$ 等营养盐水平的变化在一定程度上也会影响藻类的生长, 而叶绿素 $a$ 浓度作为衡量藻类密度及生 物量的重要指标之一, 与藻类含量变化密切相关. 水体中适量的藻类可以为底栖动物提供充足的食物来源, 促进其生长和繁殖, 提高物种丰度和生物量; 而藻类含量到达一定阈值后, 含量越高溶解氧浓度会越低, 会 致使底栖动物敏感种的多样性和物种丰富度下降 ${ }^{[52]}$. 相关性分析表明, 叶绿素 $a$ 与底栖动物的物种多样性 呈极显著的负相关关系 $(P<0.01)$. 但本研究发现, 调查河流的溶解氧浓度较高 (平均值 $9.2 \mathrm{mg} / \mathrm{L}$ ), 且叶绿 素 $a$ 浓度与溶解氧浓度之间并无明显的相关性 $(r=0.077, P=0.637)$; 但与电导率、总氮和硝酸盐氮浓度呈显 著正相关 $(P<0.05)$, 与水深、流速呈显著负相关 $(P<0.05)$. 说明叶绿素 $a$ 浓度的变化并不是造成底栖动物 多样性降低的直接原因. 推测其原因, 一方面这可能是因为喜急流、高溶解氧的 EPT 类的物种多样性会随着 流速的降低、水深的增加而发生明显下降, 另一方面还是因为营养盐水平的增高以及电导率的增加造成底 栖动物整体多样性的降低. 此外, 本文研究结果发现, 调查河流中底栖动物的群落特征与水深、水温、流速、 
溶解氧等水环境因子没有明显的相关关系,这主要是因为这 4 种水环境因子在采样点间的变化梯度差异性 不大造成的.

\section{3 渭河干流及秦岭北麓典型支流水质生物评价}

水质生物评价是指通过对水体中水生生物的调查或对水生生物的直接检测来评价水体的生物学质 量 ${ }^{[53]}$. 本文选用底栖动物 Margalef 丰富度指数和 $B I$ 指数对渭河干流及秦岭北麓典型支流的水体进行评价. 评价结果显示, 渭河干流水质基本呈轻度一中度污染状态, 5 条秦岭北麓典型支流基本呈无污染一轻度污染 状态. 水质评价结果既有相似性又有差异性. 在渭河流域的 40 个采样点上, 两种水质评价结果趋势相同, 有 $27.5 \%$ 的采样点 2 种水质评价结果一致, 有 $92.5 \%$ 的采样点水质评价等级差异不超过两级, 具体差异为 Margalef 丰富度指数法水质评价结果稍微优于 $B I$ 指数法. 从渭河干流与支流间来看, 2 种水质评价结果均显示 秦岭北麓典型支流水质要好于渭河干流. 群落丰富度指数法的水质评价结果显示, 石堤河和灞河中的采样 点水质评价等级多为清洁 (II) 及以上, 而 $B I$ 生物指数法却显示 2 条河流的水质评价多为轻污染 (III) 及以 下. 造成 2 种评价结果差异的原因主要是两种水质评价方法的评价方式和评价内容不同. 物种多样性指数 水质评价方法是通过研究群落中各物种的组成情况来反映水体受环境污染的胁迫对群落造成的影响, 而 $B I$ 指数既考虑了底栖动物的物种多样性又考虑了底栖动物的耐污能力 ${ }^{[54]}$. 石堤河和灞河的物种丰富度指数 值相对较高, 说明了河流中底栖动物的物种数较为丰富; 但 $B I$ 指数值也高, 说明在这 2 条河中底栖动物的敏 感性相对于秦岭水系的其他河流整体较低、耐受性相对较高. 底栖动物行动缓慢、生活场所比较固定, 对逆 境的逃避较缓慢. 虽然 EPT 类等清洁物种会随着污染程度的增加而逐渐消失, 但是摇蚊类、霍甫水丝蚂、软 体动物等耐污值较高的物种却会在不健康的水环境中存活下来并繁殖, 这样就使得丰富度指数变化幅度不 大. 结合理化监测数据来看, 石堤河和灞河的总氮、硝酸盐氮浓度和电导率等相对于其他支流较高, 这与 $B I$ 指数反映出的水质结果具有一致性. 这也在一定程度上可以说明, 相对于 Margalef 丰富度指数法, $B I$ 法水质 评价结果是对水环境质量更为真实的反映. 因此,河流的水质生物评价应该在多样性指数评价的基础上与 生物指数评价相结合, 并参考水环境参数检测结果, 才能更全面更可靠地体现大型底栖动物对流域水生态 环境的指示情况.

\section{4 参考文献}

[ 1 ] Xu ZX, Gu XY, Liu LF. Investigation and assessment on river health of Weihe River Basin. Water Resources Protection, 2018, 34(1) : 1-7. [徐宗学, 顾晓旳, 刘麟菲. 渭河流域河流健康调查与评价. 水资源保护, 2018, 34(1): 1-7.]

[ 2 ] Zuo DP, Xu ZX, Wu W et al. Identification of streamflow response to climate change and human activities in the Wei River Basin, China. Water Resources Management, 2014, 28(3) : 833-851. DOI: 10.1007/s11269-014-0519-0.

[ 3 ] Zhou YJ, Zhao YH, Li WY. A brief introduction to ecological problems and the research progress of soil remediation in the northern foot of Qinling Mountains. Chinese Journal of Ecology, 2019, 38(7) : 2218-2227. DOI: 10.13292/j.1000-4890. 201907.012. [周显杰, 赵永华, 李宛芗. 秦岭北麓生态问题及土壤修复研究进展. 生态学杂志, 2019, 38( 7) : 2218-2227.]

[ 4 ] Park TJ, Lee JH, Lee MS et al. Development of water quality criteria of ammonia for protecting aquatic life in freshwater using species sensitivity distribution method. Science of the Total Environment, 2018, 634: 934-940. DOI: 10.1016/j.scitotenv.2018.04.018.

[ 5 ] Ruaro R, Gubiani ÉA. A scientometric assessment of 30 years of the Index of Biotic Integrity in aquatic ecosystems: Applications and main flaws. Ecological Indicators, 2013, 29: 105-110. DOI: 10.1016/j.ecolind.2012.12.016.

[ 6 ] Yang SQ, Zu TX, Wang HB et al. Relationship between the structure of phytoplankton community and environmental. $J$ Lake Sci, 2019, 31(1): 159-170. DOI: 10.18307/2019.0115. [杨宋琪, 祖廷, 王怀斌等. 黑河张掖段浮游植物群落 结构及其与环境因子的关系. 湖泊科学, 2019, 31(1): 159-170.]

[ 7 ] Liang YL, Wang HZ eds. Benthic Animals: Chapter 10. In: Liu JK ed. Advanced aquatic biology. Beijing: Science Press, 1999: 241-259. [梁彦龄, 王洪铸. 底栖动物: 第十章. 见: 刘建康编. 高级水生生物学. 北京: 科学出版社, 1999: 241-259.]

[ 8 ] Pan BZ, Wang HJ, Li ZW et al. Macroinvertebrate assemblages in relation to environments in the Dongting Lake, with implications for ecological management of river-connected lakes affected by dam construction. Environmental Progress \& Sus- 
tainable Energy, 2016, 36(3) : 914-920. DOI: 10.1002/ep.12510.

[ 9 ] Liu LF, Xu ZX, Yin XW et al. Response of aquatic organism richness to physiochemical factors at different regions in Jinan City. J Lake Sci, 2019, 31(4) : 998-1011. DOI: 10.18307/2019.0406. [刘麟菲, 徐宗学, 殷旭旺等. 济南市不同 区域水生生物与水环境因子的响应关系. 湖泊科学, 2019, 31(4): 998-1011.]

[10] Chen L, Wang DB, Jun S. Macroinvertebrate community structure and relationships with environmental factors in the Lhasa River Basin. Acta Ecologica Sinica, 2019, 39(3) : 757-769. DOI: 10.5846/stxb201806011224. [陈丽, 王东波, 君珊. 拉萨河流域大型底栖动物群落结构及其与环境因子的关系. 生态学报, 2019, 39(3): 757-769.]

[11] Archaimbault V, Usseglio-Polatera P, Garric J et al. Assessing pollution of toxic sediment in streams using bio-ecological traits of benthic macroinvertebrates. Freshwater Biology, 2009, 55(7) : 1430-1446. DOI: 10.1111/j.1365-2427.2009. 02281.x.

[12] Tian P, Qian C, Lin JN et al. Study of river health assessment based on the benthic index of biological integrity in the Luanhe River Basin. Environmental Monitoring in China, 2019, 35(4): 50-58. [田鹏, 钱昶, 林佳宁等. 㴒河流域大型底 栖动物生物完整性指数健康评价. 中国环境监测, 2019, 35(4)：50-58.]

[13] Zuellig RE, Schmidt TS. Characterizing invertebrate traits in wadeable streams of the contiguous US: Differences among ecoregions and land uses. Freshwater Science, 2012, 31(4) : 1042-1056.

[14] Xiong CH, Zhang RL, Xu YP et al. Health assessment on rivers in Shanghai City using benthic index of biotic integrity. $J$ Lake Sci, 2015, 27(6) : 1067-1078. DOI: 10.18307/2015.0611. [熊春晖, 张瑞雷, 徐玉萍等. 应用底栖动物完整性 指数评价上海市河流健康. 湖泊科学, 2015, 27(6): 1067-1078.]

[15] Feng LH, Gu JJ, Qi X et al. The Community structure of macrobenthos and bioassessment of water quality of the Yong'an stream in Zhejiang Province. Genomics and Applied Biology, 2017, 36 ( 7 ) : 2849-2861. DOI: 10. 13417/j. gab.036. 002849. [冯立辉, 顾婧婧, 齐金金等. 浙江永安溪大型底栖动物群落结构及水质生物学评价. 基因组学与应用生物 学, 2017, 36(7): 2849-2861.]

[16] Kärnä OM, Heino J, Grönroos M et al. The added value of geodiversity indices in explaining variation of stream macroinvertebrate diversity. Ecological Indicators, 2018, 94: 420-429. DOI: 10.1016/j.ecolind.2018.06.034.

[17] Yin XW, Li QN, Zhu MH et al. Community structure and biological integrity of macroinvertebrates in the wet and dry seasons of Wei River basin, China. Acta Ecologica Sinica, 2015, 35(14) : 4784-4796. [殷旭旺, 李庆南, 朱美桦等. 渭河 丰、枯水期底栖动物群落特征及综合健康评价. 生态学报, 2015, 35(14) : 4784-4796.]

[18] Yin XW, Xu ZX, Gao X et al. Macrobenthos community structure and its relationships with environmental factors in Weihe River basin, Northwest China. Chinese Journal of Applied Ecology, 2013, 24(1) : 218-226. [殷旭旺, 徐宗学, 高欣等. 渭河流域大型底栖动物群落结构及其与环境因子的关系. 应用生态学报, 2013, 24(1): 218-226.]

[19] Chen DS, Li J, Yang XN et al. Trade-offs and optimization among ecosystem services in the Weihe River basin. Acta Ecologica Sinica , 2018, 38(9): 3260-3271. DOI: 10.5846/stxb201707011187. [陈登帅, 李晶, 杨晓楠等. 渭河流域生 态系统服务权衡优化研究. 生态学报, 2018, 38(9): 3260-3271.]

[20] Shang H. Study on the water resources and ecological environment in the Weihe River. Research of Soil and Water Conservation, 2007, 14(5): 89-92. [尚华. 陕西渭河流域水资源与生态问题研究. 水土保持研究, 2007, 14(5): 89-92.]

[21] Jing LH. The role of the Hanjiang-to-Weihe river water diversion project on water shortage and environmental problem in Weihe River Basin. China Water Resources, 2015, (14): 73-75. [景来红. 引汉济渭工程对解决渭河流域缺水及生态 环境问题的作用. 中国水利, 2015, (14): 73-75.]

[22] Epler JH. Identification manual for the larval chironomidae( Diptera) of North and South Carolina. America: EPA Grant\# X984170-97. 2001: 1-500.

[23] Morse JC, Yang LF, Tian LX eds. Aquatic insects of China useful for monitoring water quality. Nanjing: Hohai University Press, 1994: 1-568.

[24] Brinkhurst RO. Guide to the freshwater aquatic microdrile Oligochaetes of North America. Freshwater Science, 1987, 6 (1): 78-79.

[25] Editorial board of "Water and wastewater monitoring and analysis method", Ministry of Environmental Protection of the People's Republic of China ed. Monitoring and analysis methods of water and wastewater: third edition. Beijing: China Environment Science Press, 1989. [国家环境保护总局《水和废水监测分析方法》编委会. 水和废水监测分析方法: 第 3 版. 北京: 中国科学出版社, 1989.] 
[26] Chen YW, Chen KN, Hu YH. Discussion on possible error for phytoplankton chlorophyll-a concentration analysis using hot-ethanol extraction method. J Lake Sci, 2006, 18(5) : 550-552. DOI: 10.18307/2006.0519. [陈宇炜，陈开宁, 胡耀 辉. 浮游植物叶绿素 a 测定的“热乙醇法”及其测定误差的探讨. 湖泊科学, 2006, 18(5) : 550-552.]

[27] Cummins KW. An evaluation of some techniques for the collection and analysis of benthic samples with special emphasis on lotic waters. American Midland Naturalist, 1962, 67(2): 477-504.

[28] Wang BX. Water quality bioassessment using benthic macroinvertebrate [Dissertation]. Nanjing: Nanjing Agricultural University, 2003. [王备新. 大型底栖无脊椎动物水质生物评价研究 [ 学位论文]. 南京: 南京农业大学, 2003.]

[29] Karr JR. Biological monitoring and environmental assessment: a conceptual framework. Environmental Management, 1987, 11(2) : 249-256.

[30] Gerritsen J. Additive biological indices for resource management. Journal of the North American Benthological Society, $1995, \mathbf{1 4}(3)$ : 451-457.

[31] Barbour MT, Gerritsen J, Griffith GE et al. A framework for biological criteria for Florida streams using benthic macroinvertebrates. Journal of the North American Benthological Society, 1996, 15(2) : 185-211.

[32] Maxted JR, Barbour MT, Gerritsen J et al. Assessment framework for mid-Atlantic coastal plain streams using benthic macroinvertebrates. Journal of the North American Benthological Society, 2000, 19(1) : 128-144.

[33] Wang JG, Huang HB, Yang MX et al. Tolerance values of benthic macroinvertebrates and bioassessment of water quality in the Lushan Nature Reserve. Chinese Journal of Applied and Environmental Biology, 2003, (3): 279-284. [王建国, 黄恢 柏, 杨明旭等. 庐山地区底栖大型无脊椎动物耐污值与水质生物学评价. 应用与环境生物学报, 2003, (3): 279-284. ]

[34] Wang BX, Yang LF. A study on tolerance values of benthic macroinvertebrate taxa in eastern China. Acta Ecologica Sinica, 2004, 24(12) : 2768-2775. [王备新, 杨莲芳. 我国东部底栖无脊椎动物主要分类单元耐污值. 生态学报, 2004, $24(12): 2768-2775$. ]

[35] Qin CY, Zhou J, Cao Y et al. Quantitative tolerance values for common stream benthic macroinvertebrates in the Yangtze River Delta, Eastern China. Environmental Monitoring and Assessment, 2014, 186(9) : 5883-5895.

[36] Zhao R, Gao X, Ding S et al. Tolerance values of macroinvertebrate taxa in Liao River basin. Acta Ecologica Sinica, 2015, 35(14)：4797-4809. [ 赵瑞, 高欣, 丁森等. 辽河流域大型底栖动物耐污值. 生态学报, 2015, 35 (14): 4797-4809.]

[37] Shannon CE, Weaver WJ eds. The mathematical theory of communication. Urbana: University of Illinois Press, 1949: 296.

[38] Margalef DR. Information theory in ecology. Generation Systems, 1957, 3: 36-71.

[39] Pielou EC. The measurement of diversity in different types of biological collections. Journal of Theoretical Biology, 1966, 13: 131-144.

[40] Brazner JC, Beals EW. Patterns in fish assemblages from coastal wetland and beach habitats in Green Bay, Lake Michigan: A multivariate analysis of abiotic and biotic forcing factors. Canadian Journal of Fisheries and Aquatic Science, 1997 , 54(8): 1743-1761.

[41] Zhu PH, Pan BZ, Li ZW et al. Macroinvertebrate communities characteristics and their responses to fluvial geomorphological feature of typical debris flow gullies in the Xiaojiang River Basin, Yunnan Province. J Lake Sci, 2019, 31(3) : 869880. DOI: 10.18307/2019.0325. [ 朱朋辉, 潘保柱, 李志威等. 云南小江流域典型泥石流沟中底栖动物群落特征及 其对河流地貌的响应. 湖泊科学, 2019, 31(3) : 869-880.]

[42] Beisel J, Usseglio-Polatera P, Thomas S et al. Stream community structure in relation to spatial variation: The influence of mesohabitat characteristics. Hydrobiologia, 1998, 389(1/2/3) : 73-88. DOI: 10.1023/A:1003519429979.

[43] Frissell CA, Liss WJ, Warren CE et al. A hierarchical framework for stream habitat classification: Viewing streams in a watershed context. Environmental Management, 1986, 10(2) : 199-214.

[44] Wang S, Lin YQ, Chen QW et al. The spatial and temporal distribution of macroinvertebrates community and water quality bioassessment in Lijiang River. Acta Scientiae Circumstantiae, 2018, 38(3) : 1207-1213. DOI: 10.13671/j.hjkxxb.2017. 0342. [王硕, 林育青, 陈求稳等. 漓江大型底栖动物群落时空分布及水质生物评价. 环境科学学报, 2018,38 (3) : 1207-1213.]

[45] Yang D, Zhou ZQ, Zhang JS et al. Characteristics of macrobenthic communities at the Muping marine ranch of Yantai in 
summer. Marine Sciences, 2017, 41(5)：134-143. [杨东, 周政权, 张建设等. 烟台牟平海洋牧场夏季大型底栖动物 群落特征. 海洋科学, 2017, 41(5): 134-143.]

[46] Shao ML, Han XQ, Xie ZC et al. Comparative on macroinvertebrate communities along a cascade of reservoirs in Xiangxi River Basin. Acta Ecologica Sinica, 2007, 27(12)：4963-4971. [邵美玲, 韩新芹, 谢志才等. 香溪河流域梯级水库 底栖动物群落比较. 生态学报, 2007, 27(12): 4963-4971.]

[47] Scheuhammer AM, Mcnicol DK, Mallory ML et al. Relationships between lake chemistry and calcium and trace metal concentrations of aquatic invertebrates eaten by breeding insectivorous waterfowl. Environmental Pollution, 1997, 96(2) : 235-247.

[48] Buss D, Baptista DF, Silveira MP et al. Influence of water chemistry and environmental degradation on macroinvertebrate assemblages in a river basin in south-east Brazil. Hydrobiologia, 2002, 481 ( 1/2/3): 125-136. DOI: 10. 1023/ A : 1021281508709 .

[49] Shen HY, Cao ZH, Liu JW et al. Relationship between functional feeding groups of macroinvertebrates and environmental factors in Taizi River basin. China Environmental Science, 2015, 35(2) : 579-590. [沈洪艳, 曹志会, 刘军伟等. 太子 河流域大型底栖动物功能摄食类群与环境要素的关系. 中国环境科学, 2015, 35(2): 579-590.]

[50] Gao X, Niu CJ, Hu ZJ. Macrobenthos community structure and its relations with environmental factors in Taihu River basin. Chinese Journal of Applied Ecology, 2011, 22(12) : 3329-3336. [高欣, 牛翠娟, 胡忠军. 太湖流域大型底栖动物 群落结构及其与环境因子的关系. 应用生态学报, 2011, 22(12) : 3329-3336. $]$

[51] Zhao Q, Jia XB, Xia R et al. A field-based method to derive macroinvertebrate benchmark for specific conductivity adapted for small data sets and demonstrated in the Hun-Tai River Basin, Northeast China. Environmental Pollution, 2016, 216 : 902-910.

[52] Stout RJ, Taft WH. Growth patterns of a chironomid shredder on fresh and senescent tag alder leaves in two Michigan streams. Journal of Freshwater Ecology, 1985, 3(2): 147-153.

[53] Sheng X, Mao JZ, Cao R et al. River health assessment based on five biological indices for macroinvertebrates. Water Resources Protection, 2017, 33(1):75-82. [ 盛萧, 毛建忠, 曹然等. 基于 5 种大型底栖动物评价指数的河流生态健康 评价. 水资源保护, 2017, 33(1): 75-82.]

[54] Wu DH, Wang BX, Zhang Y et al. Advances in the use of biotic index for water quality bioassessment with benthic macroinvertebrate and its perspective in China. Journal of Nanjing Agricultural University, 2011, 34(2) : 129-134. [吴东浩, 王备新, 张咏等. 底栖动物生物指数水质评价进展及在中国的应用前景. 南京农业大学学报, 2011, 34(2): 129-134.] 